\title{
Effects of live weight and energy intake on nitrogen balance and total $\mathrm{N}$ requirement of lambs
}

\author{
BY J. L. BLACK \\ CSIRO, Division of Animal Physiology, \\ Ian Clunies Ross Animal Research Laboratory, \\ Prospect, PO Box 239, Blacktown, New South Wales 2148, Australia \\ AND D. A. GRIFFITHS \\ CSIRO, Division of Mathematical Statistics, \\ Newtown, New South Wales 2042, Australia
}

(Received 2 fuly 1974-Accepted 10 October 1974)

1. Results of 298 nitrogen balance studies from experiments with male cross-bred lambs, ranging in weight from 3 to $38 \mathrm{~kg}$, which had been either fasted, or fed entirely on liquid diets of varying protein content at various energy intakes up to ad lib. intake, were used to quantitatively describe the effects of the amount and quality of absorbed protein, energy intake and live weight on $\mathrm{N}$ balance and total $\mathrm{N}$ requirement of lambs.

2. When $N$ intake was less than the amount required, $\mathbf{N}$ balance was independent of energy intake, but linearly related to absorbed $\mathrm{N}$ and metabolic body-weight (live weight ${ }^{0.75}$ ). In the fitted relationship, the coefficient of absorbed $N$ was shown to be an estimate of the biological value of absorbed protein and the coefficient of metabolic body-weight was an estimate of the loss of endogenous $\mathrm{N}$ in both urine and faeces. For the milk-based diets used in the experiment biological value was 0.72 and the total endogenous $N$ loss in urine and faeces was $148 \mathrm{mg} \mathrm{N} / \mathrm{kg}^{0 \cdot 75}$ per $\mathrm{d}$.

3. When $\mathrm{N}$ intake was in excess of the amount required, $\mathrm{N}$ balance in lambs of a constant live weight increased linearly with metabolizable energy (ME) intake, at a rate that decreased with increasing live weight. Similarly at constant $\mathrm{ME}$ intake, $\mathrm{N}$ balance was a curvilinear decreasing function of metabolic body-weight. When $\mathrm{N}$ balance was expressed per unit metabolic body-weight, it was constant for lambs of all weights when ME intake was about $0.23 \mathrm{MJ} / \mathrm{kg}^{0.75}$ per $\mathrm{d}$, but it decreased linearly with increasing metabolic body-weight for ME intakes above this level.

4. $\mathrm{N}$ balance of fasted lambs was several times less than predicted by either of the relationships established for fed animals, and was found to be linearly related to metabolic bodyweight.

5. The effects of energy intake and live weight on the total $N$ requirement of lambs were determined. When total $\mathrm{N}$ requirement was expressed per unit of energy intake, it was found to be constant at $0.9 \mathrm{~g} \mathrm{~N} / \mathrm{MJ} \mathrm{ME}$ for all lambs irrespective of live weight when ME intake was $0.23 \mathrm{MJ} / \mathrm{kg}^{0.75}$ per d. However, as $\mathrm{ME}$ intake/unit metabolic body-weight was raised above this level, $\mathrm{N}$ requirement/unit $\mathrm{ME}$ intake increased for lambs weighing less than $c .23 \mathrm{~kg}$, but decreased for heavier animals.

It has been suggested (Black, Pearce \& Tribe, 1973) that much of the variation in estimates of the protein requirements of lambs results from failure to differentiate between the total needs of the animal's tissues for nutrients and the capacity of different diets to provide the tissues with these nutrients. Failure to make this distinction means that most estimates of protein requirements are applicable only to the very limited conditions of the particular experiments from which they were derived. Because the requirement of the tissues for a nutrient in animals of a similar breed, sex and physiological state is relatively constant and the availability of that nutrient 
from different diets often highly variable, the tissue requirement for that nutrient must be known before information on its availability can be used in the formulation of diets, or for the prediction of animal performance.

To obtain a concise definition of the tissue requirements of animals for nitrogenous compounds, it is essential to define (a) the total nitrogen requirement of the animals, (b) the minimum amount of this total $\mathrm{N}$ requirement which must be supplied from each of the essential amino acids, and $(c)$ how these requirements are influenced by the physiological state of the animals and environmental conditions. It has been recognized for many years that both the stage of maturity and the level of energy intake have a great effect on the $\mathrm{N}$ metabolism of animals and, therefore, on their requirement for $\mathrm{N}$. These interrelationships have been described for several species in qualitative terms (Munro, 1964; Preston, 1966; Balch, 1967; Ørskov, 1970), but there has not been sufficient information for any one species to allow a quantitative description.

In a previous study (Black et al. 1973) the total $\mathrm{N}$ requirements were established for lambs ranging in live weight from 8 to $30 \mathrm{~kg}$ and given energy at a level of approximately three times that required for maintenance. These results were expressed in terms of reference-protein (total $\mathrm{N}$ requirement $\times 6.25$ )/unit net energy as a preliminary measure until the precise requirement for essential amino acids in growing lambs has been determined.

Because of the limited range of energy intake in the previous experiment, a further 224 values from varying sources of lambs ranging widely in both live weight and intake, have been included in this paper. The combined results have been used to assess more precisely the effects of live weight and energy intake on the total $\mathrm{N}$ requirement of lambs. So that the quantity of $\mathrm{N}$ absorbed by the animals could be accurately assessed, only non-ruminant lambs were studied. However, with several small modifications (Black et al. 1973), the results obtained from these animals should be applicable to ruminant lambs of the same tissue weight.

\section{EXPERIMENTAL}

\section{General}

All results were obtained for uncastrated male cross-bred (Merino $ᄋ \times$ Border

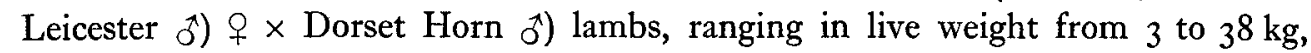
and either fasted or fed entirely on liquid diets of varying protein content at various energy intakes up to ad lib. intake. Most of the lambs weighing less than $15 \mathrm{~kg}$ drank their rations from a teat, whereas most of those weighing more than $15 \mathrm{~kg}$ were fed by abomasal infusion.

The sources of results and the ranges of live weight and gross energy intake of the lambs, as well as the range of protein content of the experimental diets, are given in Table I.

The experimental procedure adopted for the lambs of Black (unpublished results) were the same as those used by Black et al. (1973), except that all the diets were infused directly into the abomasum over a $22 \mathrm{~h}$ period each day. Catheters were inserted into 
Table x. Range of live weights and gross energy intakes of lambs and range of protein contents of their diets, as reported by several workers

Source

Black, Pearce \& Tribe (1 973)

J. L. Black (unpublished results)

N. McC. Graham (unpublished results)

Hodge (197x)

Norton \& Walker (1971 $a$ )

Norton \& Walker (197 $\mathrm{b}$ )

Walker, (1967)

Walker \& Cook ( I 967)

Walker, Cook \& Jagusch (1967)

Walker \& Norton (197 I $a$ )

\begin{tabular}{|c|c|c|c|}
\hline $\begin{array}{l}\text { No. of } \\
\text { values }\end{array}$ & $\begin{array}{c}\text { Live } \\
\text { weight }(\mathrm{kg})\end{array}$ & $\begin{array}{c}\text { Gross } \\
\text { energy } \\
\text { intake } \\
\left(\mathrm{MJ} / \mathrm{kg}^{0.75}\right. \\
\text { per d) }\end{array}$ & $\begin{array}{l}\text { Protein } \\
\text { content } \\
\text { of diets } \\
\text { ( } \mathrm{g} / \mathrm{kg} \mathrm{dry} \\
\text { matter) }\end{array}$ \\
\hline $\begin{array}{r}74 \\
27 \\
40 \\
8\end{array}$ & $\begin{array}{r}7 \cdot 3-31 \cdot 5 \\
6 \cdot 5-26 \cdot 7 \\
6 \cdot 5-38 \cdot 2 \\
14 \cdot 2-26 \cdot 3\end{array}$ & $\begin{array}{c}1.06-1.42 \\
0.18-1.41 \\
0.00 \\
0.99-1.67\end{array}$ & $\begin{array}{c}100-400 \\
290 \\
0 \\
285\end{array}$ \\
\hline 149 & $3 \cdot 0-14 \cdot 0$ & $0.00-1.90$ & $0-455$ \\
\hline
\end{tabular}

these lambs by the Witzel's gastrostomy technique (Markowitz, Archibald \& Downie, I 964 ) at least $14 \mathrm{~d}$ before $\mathrm{N}$ balance studies were started.

The experimental procedure adopted for the lambs of N. McC. Graham (unpublished results) were described by Graham, Searle \& Griffiths (1974).

\section{Statistical procedures}

Relationships between $N$ balance and regressor variables were investigated through multiple regression analyses. Some regression equations were constrained to pass through the origin. In these instances the usual coefficient of determination $\left(R_{\mathrm{I}}^{2}\right)$ of the regression did not apply, and a 'modified coefficient of determination' $\left(R^{2}\right)$ was adopted as an analogous descriptive term. This type of index was suggested by Cornish (1950) and may be defined as:

$$
R_{\mathrm{I}}^{2}=\mathrm{I}-\frac{\Sigma\left(Y_{\mathrm{i}}-\hat{Y}_{\mathrm{i}}\right)^{2}}{\Sigma\left(Y_{\mathrm{i}}-\bar{Y}\right)^{2}},
$$

where $\hat{Y}_{1}$ is the estimated value corresponding to the ith observation, $Y_{1}$; and $\bar{Y}=\frac{\mathrm{I}}{n} \Sigma Y_{\mathrm{i}}$.

\section{RESULTS}

\section{Effects of live weight, energy intake and $N$ intake on $N$ balance}

The relationship between $\mathrm{N}$ intake and $\mathrm{N}$ balance for all results obtained is shown in Fig. I. Although the values were widely scattered, a close examination of the results showed that a consistent relationship exists for non-fasted animals of any given live weight and encrgy intake. Fig. I also shows this relationship for lambs of about $7 \mathrm{~kg}$ given a gross energy intake of about $6 \mathrm{MJJ} / \mathrm{d}$. By statistical examination of the results obtained it has been found that the response curve for animals of a similar live weight and encrgy intake may be adequately described by two straight lines (Hegsted \& Neff, 1970; Black et al. 1973). The upper line, which represents the $\mathrm{N}$ balance when $\mathrm{N}$ intake is in excess of requirement, is horizontal. Further examination 


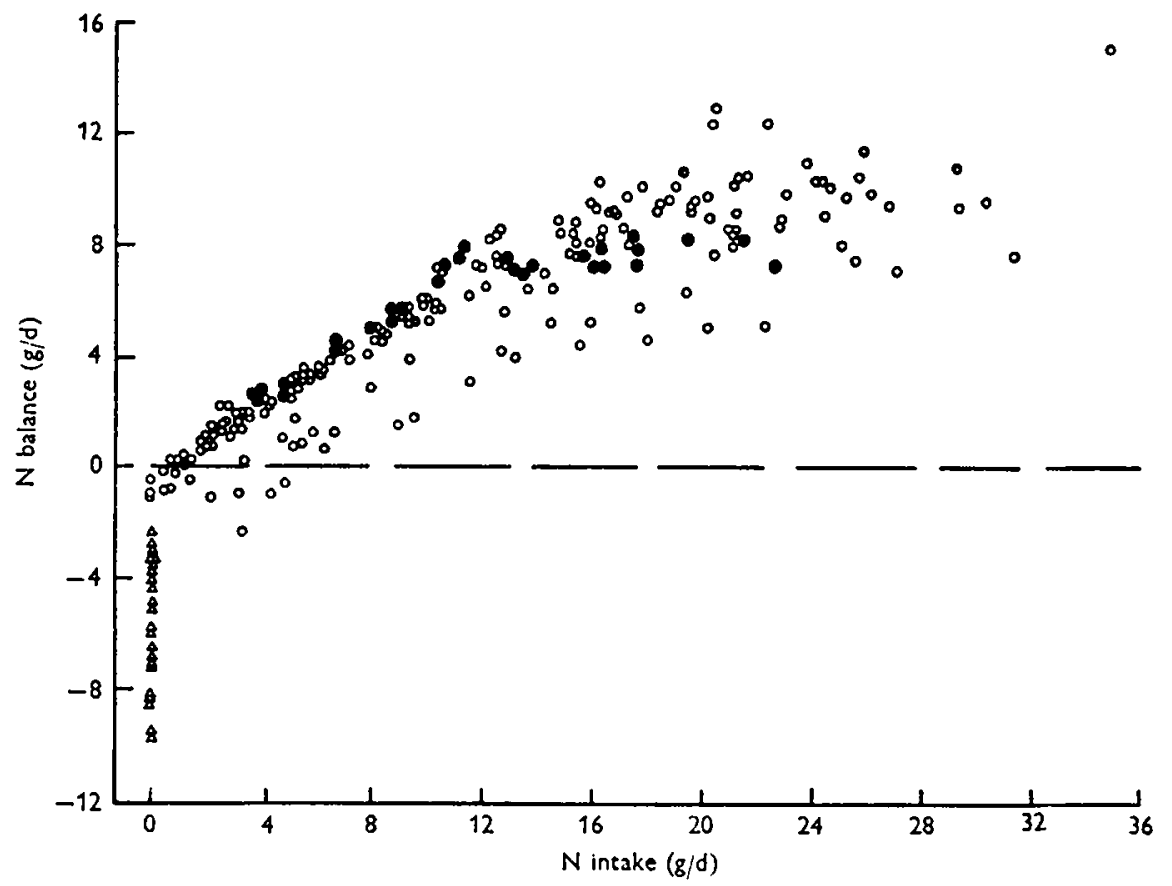

Fig. r. Relationship between nitrogen balance and $\mathrm{N}$ intake for all results obtained for lambs which were either fasted $(\Delta)$, or fed on liquid diets of varying protein contents at various energy intakes up to $a d$ lib. intake $(O) ; O$, lambs ranging in live weight from 6.3 to $8.4 \mathrm{~kg}$ and in gross energy intake from 5.5 to $6.9 \mathrm{MJ} / \mathrm{d}$. For details, see Table I.

of the present results showed that the position of this upper line was markedly influenced by both live weight and energy intake but not by $\mathrm{N}$ intake. In addition, whenever $\mathrm{N}$ balance was limited by a low $\mathrm{N}$ intake, all points fell near the upper left hand edge of the scatter irrespective of energy intake.

To obtain suitable mathematical descriptions of the effects of live weight, energy intake and $\mathrm{N}$ intake on $\mathrm{N}$ balance, the results were initially divided into four groups: (a) results for animals which were given diets considered to be deficient in $\mathrm{N}$ (assessed by the fact that other lambs of similar live weight and energy intake responded to increases in $\mathrm{N}$ intake ( 1 I 0 values); (b) results for animals which were given diets considered to contain excess $N$ (assessed by the fact that similar animals did not respond to increases in $\mathrm{N}$ intake) (ninety-two values); (c) results for fed animals which did not fall clearly into either group $a$ or $b$ (fifty values); $(d)$ results for fasted animals (forty-five values). Separate relationships were established for the results from groups $a, b$ and $d$. Each result from group $c$ was examined to determine which group rclationship ( $a$ or $b$ ) it most closely fitted. As a consequence of this examination all were included in group $b$. The relationship for this group was then re-established and was not substantially altered by the additional results.

$\mathrm{N}$ balance for groups $a, b$ and $d$ were distinguished by the use of the subscripts, lim ( $\mathrm{N}$ limiting), exc ( $\mathrm{N}$ excess) and fst (fasting) respectively. 


\section{$N$ balance when $N$ intake was limiting}

Because $\mathrm{N}$ metabolism in animals is closely related to energy metabolism (Brody, 1945), N metabolism, like energy metabolism, is probably linearly related to an exponent of live weight which is less than unity. 'There is no commonly adopted exponent of live weight for growing animals. The optimum exponent for the lambs given $\mathrm{N}$-deficient diets was, therefore, determined by evaluation of the least squares estimates of $a, b$ and $x$ in the following equation:

$$
\mathrm{NB}_{1 \mathrm{~mm}}=a \mathrm{NI}+b \mathrm{~W}^{x},
$$

where $\mathrm{NB}_{1 \mathrm{~mm}}$ is $\mathrm{N}$ balance $(\mathrm{g} / \mathrm{d}), \mathrm{NI}$ is $\mathrm{N}$ intake $(\mathrm{g} / \mathrm{d})$ and $\mathrm{W}$ is live weight $(\mathrm{kg})$ of lambs. The least squares estimates were evaluated iteratively and a linear approximation to the model gave approximate standard errors for estimates of $a, b$ and $x$.

The fitted equation was:

$$
\begin{aligned}
\mathrm{NB}_{1 \mathrm{~m}}= & \left.0.720 \mathrm{NI}-0.185 \mathrm{~W}^{0.652} \quad \text { (residual SD } 0.32, R^{2} 0.98\right) . \\
& \mathrm{SE} 0.012 \mathrm{SE} 0.029 \mathrm{SE} 0.066
\end{aligned}
$$

The estimated exponent of live weight $(0.65)$ was significantly less than unity, but not significantly different from the value of 0.75 commonly used to relate metabolic rate to live weight in adult animals (Kleiber, 1969). Live weight ${ }^{0.75}$ (metabolic bodyweight, $\mathrm{W}_{\mathrm{m}}, \mathrm{kg}^{0 \cdot 75}$ ) was therefore adopted for the remaining calculations in this paper.

The relationship for the lambs given diets deficient in $\mathrm{N}$ became

$$
\begin{aligned}
\mathrm{NB}_{1 \mathrm{~m}}= & 0.723 \mathrm{NI}-0.148 \mathrm{Wm} \text { (residual SD 0.32, } R^{2} 0.98 \text { ). } \\
& \text { SE } 0.012 \text { SE } 0.013
\end{aligned}
$$

$\mathrm{N}$ balance in a $\mathrm{N}$-free diet was therefore estimated to be $-0.148 \mathrm{~W}_{\mathrm{m}}$. Therefore $0.148 \mathrm{~W}(\mathrm{~g} / \mathrm{d})$ was an estimate of the total endogenous $\mathrm{N}$ loss in urine and in faeces. The coefficient $(0.723)$ of NI in equation I provided an estimate of the biological value (BV) of the absorbed $\mathrm{N}$. This was derived as follows. The $\mathrm{BV}$ is that part of absorbed $\mathrm{N}$ retained by an animal and has been defined by the Agricultural Research Council $\left(\mathrm{I}_{9} 65\right)$ as:

$$
\mathrm{BV}=\frac{\mathrm{NI}-(\mathrm{FN}-\mathrm{MFN})-(\mathrm{UN}-\mathrm{EUN})}{\mathrm{NI}-(\mathrm{FN}-\mathrm{MFN})},
$$

where FN is faecal N, MFN is metabolic faecal N, UN is urinary N and EUN is endogenous urinary $\mathrm{N}$. $\mathrm{NB}_{\text {lim }}$ may now be defined by the equation:

$$
\mathrm{NB}_{1 \mathrm{lim}}=\mathrm{NI}-(\mathrm{FN}+\mathrm{UN}) \text {, }
$$

and absorbed $\mathrm{N}(\mathrm{NA})$ is defined by the equation:

$$
\mathrm{NA}=\mathrm{NI}-(\mathrm{FN}-\mathrm{MFN}) \text {. }
$$

Therefore, by substituting in equation 2 and then rearranging it, the equation becomes:

$$
\mathrm{NB}_{\text {lim }}=\mathrm{BV} \times \mathrm{NA}-(\mathrm{MFN}+\mathrm{EUN}) .
$$

For lambs fed on the liquid diets described in this paper, all dietary $\mathrm{N}$ was truly digested (Norton, 1968; Black et al. 1973), i.e. $\mathrm{MFN}=\mathrm{FN}$, therefore NA = NI. 


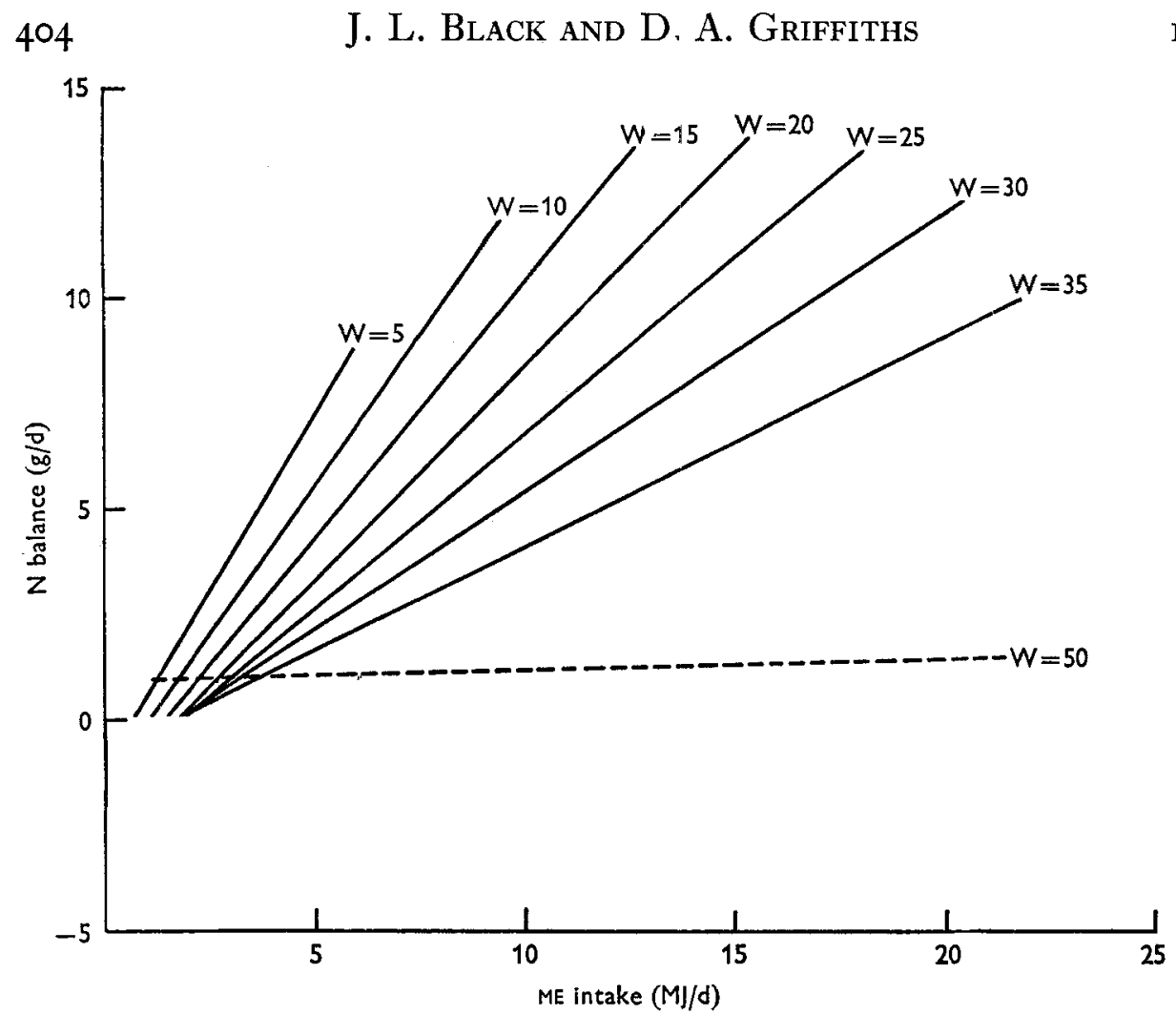

Fig. 2. Fitted relationship between nitrogen balance (g/d) and metabolizable energy (ME) intake $(\mathrm{MJ} / \mathrm{d})$ of lambs, when $\mathrm{N}$ intake was in excess of requirement, at different live weights $(\mathrm{W}, \mathrm{kg}) .---$, Extrapolation beyond the range of experimental results.

It follows that 0.723 was an estimate of the $\mathrm{BV}$ of absorbed $\mathrm{N}$ and that $0.14^{8} \mathrm{Wm}_{\mathrm{m}}$ was an estimate of (MFN $+\mathrm{EUN})$.

\section{$N$ balance when $N$ intake was in excess}

A multiple regression equation relating $\mathrm{N}$ balance $\left(\mathrm{NB}_{\text {exc }}, \mathrm{g} / \mathrm{d}\right)$ to $\mathrm{W}_{\mathrm{m}}\left(\mathrm{kg}^{\mathbf{0} \cdot 75}\right)$ and metabolizable energy intake (ME, MJ/d) was established for the lambs given excess dietary $N$. Initially all terms for $W_{m}$ and $M E$ intake up to and including quadratic terms were included in the equation, but subsequently those terms which did not contribute significantly $(P>0.05)$ to the regression equation were excluded. The fitted equation was:

$$
\begin{aligned}
& \mathrm{NB}_{\text {exc }}=2.017 \mathrm{ME}-0.40 \mathrm{r} \mathrm{W}_{\mathrm{m}}-0.106 \mathrm{~W}_{\mathrm{m}} \times \mathrm{ME}+0.024 \mathrm{~W}_{\mathrm{m}}^{2} \\
& \text { SE 0.104 SE 0.IO6 SE 0.OII SE O.OII }
\end{aligned}
$$

$$
\text { (residual SD 0.89, } R_{\mathrm{I}}^{2} 0.93 \text { ). }
$$

It follows from equation 4 that for animals of a constant live weight given excess dietary $\mathrm{N}, \mathrm{N}$ balance was linearly related to $\mathrm{ME}$ intake. For a unit increase in ME intake, the estimated change in $\mathrm{N}$ balance was given by $2 \cdot 017-0.106 \mathrm{~W}_{\mathrm{m}}$. Thus, at higher live weights, a unit increase in ME produced a smaller increase in $\mathrm{N}$ balance (Fig. 2). 
Vol. 33
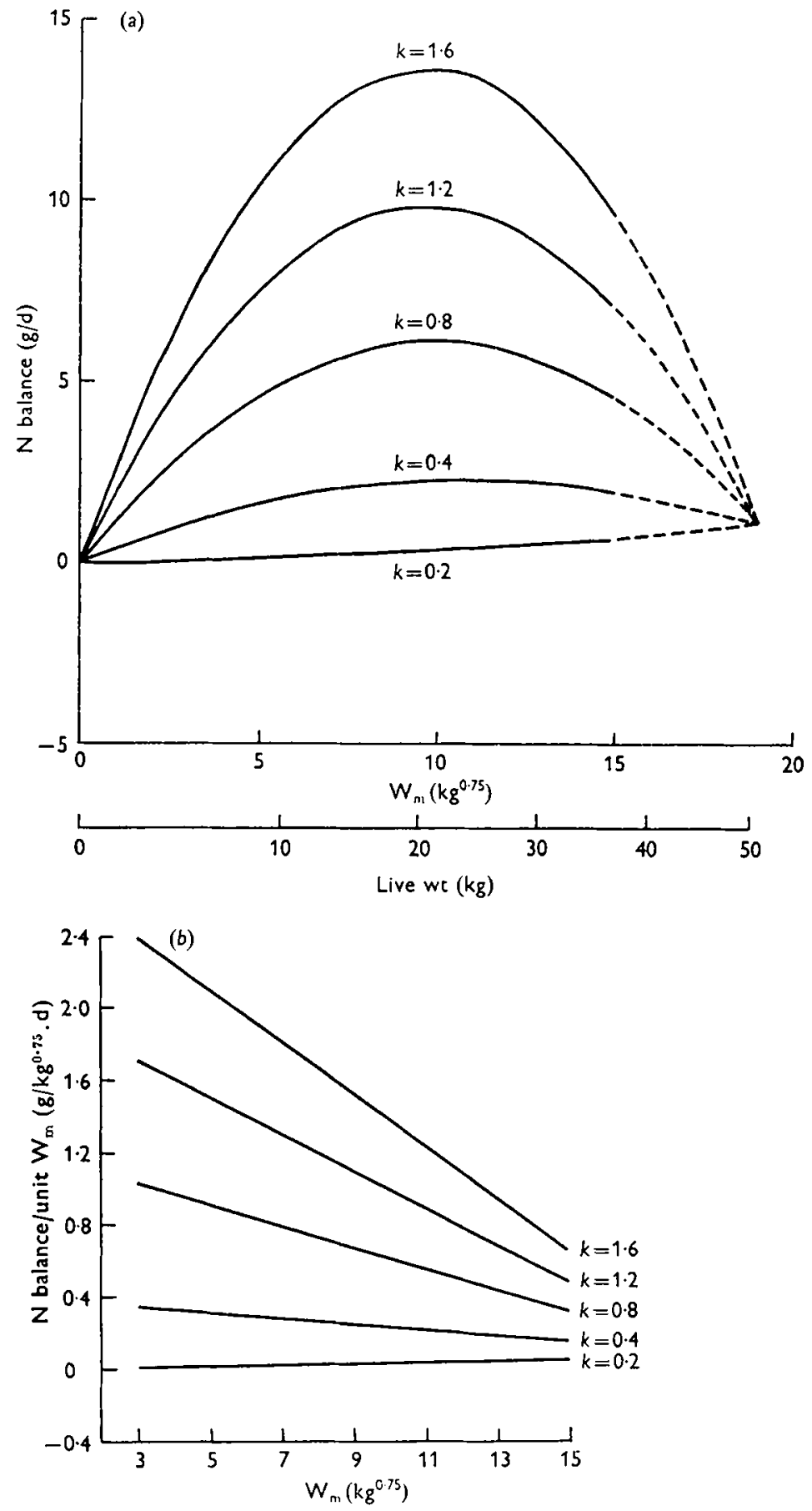

Fig. 3. Fitted relationship between (a) nitrogen balance $(\mathrm{g} / \mathrm{d})$ and $(b) \mathrm{N}$ balance/unit metabolic body-weight $\left(\mathrm{W}_{\mathrm{m}}\right)\left(\mathrm{g} / \mathrm{kg}^{0 \cdot 75}\right.$ per $\left.\mathrm{d}\right)$ and live weight $(\mathrm{kg})$ and $\mathrm{W}_{\mathrm{m}}\left(\mathrm{kg}^{0} \cdot 75\right)$ for lambs at various intakes of metabolizable energy/unit $\mathrm{W}_{\mathrm{m}}\left(k ; \mathrm{MJ} / \mathrm{kg}^{0.75}\right.$ per $\left.\mathrm{d}\right) .----$, Extrapolation beyond the range of experimental results. 


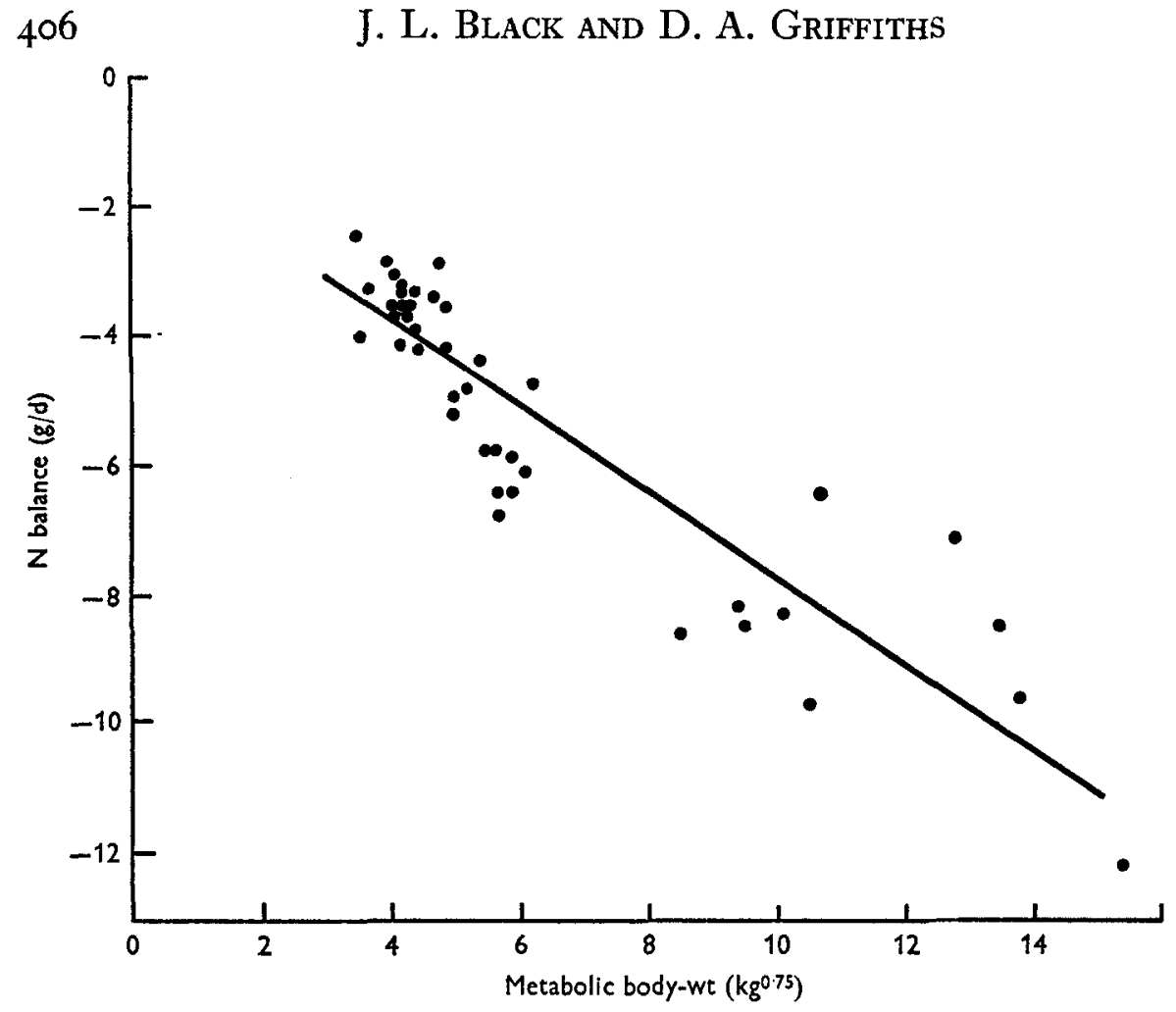

Fig. 4. Relationship between nitrogen balance $(\mathrm{g} / \mathrm{d})$ and metabolic body-weight $\left(\mathrm{kg}^{0 \cdot 75}\right)$ for lambs fasted for $2-4 \mathrm{~d}$. The fitted regression line is shown.

Extrapolation of the relationship to live weights beyond those of the heaviest experimental animals was not strictly valid, but suggested that for animals weighing approximately $50 \mathrm{~kg}\left(\mathrm{~W}_{\mathrm{m}}=19 \cdot 0=2 \cdot 017 \div 0 \cdot 106\right)$ energy intake would have no effect on $\mathrm{N}$ balance and that for heavier animals the effect of increasing $\mathrm{ME}$ intake would be to decrease $\mathrm{N}$ balance.

It may also be seen from equation 4 that, at constant $\mathrm{ME}$ intake, $\mathrm{N}$ balance in lambs given excess dietary $\mathrm{N}$ was a curvilinear function of $\mathrm{W}_{\mathrm{m}}$ and decreased over the range of the experimental results. To facilitate comparisons between animals of different live weights but similar energy intakes relative to maintenance requirements, equation 4 was examined when $\mathrm{ME}$ intake was taken to be proportional to $\mathrm{W}_{\mathrm{m}}$ (i.e. $\mathrm{ME}=k \mathrm{~W}_{\mathrm{m}}$ ). The equation may be written as $\mathrm{NB}_{\text {exc }}=(2.0 \mathrm{I} 7 k-0.40 \mathrm{I}) \mathrm{W}_{\mathrm{m}}+(0.024-0.106 k) \mathrm{W}_{\mathrm{m}}{ }^{2}$. The relationship between $\mathrm{N}$ balance and $W_{m}$ for several values of $k$ is given in Fig. $3 a$. It follows from the equation, and is apparent in Fig. $3 a$, that when $k$ was approximately $0.23(0.024 \div 0.106), \mathrm{N}$ balance was a linear function of $\mathrm{W}_{\mathrm{m}}$, and the rate of change in $\mathrm{N}$ balance/unit increase in $\mathrm{W}_{\mathrm{m}}$ was constant. When $k>0.23$, $\mathrm{N}$ balance was a concave quadratic function of $\mathrm{W}_{\mathrm{m}}$, first increasing and then decreasing, whereas when $k<0.23$, it was a convex function of $\mathrm{W}_{\mathrm{m}}$. The biological significance of these effects of changes in $\mathrm{W}_{\mathrm{m}}$ on $\mathrm{N}$ balance are more clearly shown in Fig. $3 b$, where $\mathrm{N}$ balance/unit $\mathrm{W}_{\mathrm{m}}$ is plotted $v . \mathrm{W}_{\mathrm{m}}$ for the same values of $k$ as in Fig, $3 a$. It can be seen that $\mathrm{N}$ balance/unit $\mathrm{W}_{\mathrm{m}}$ was constant when $\mathrm{ME}$ intake was about 


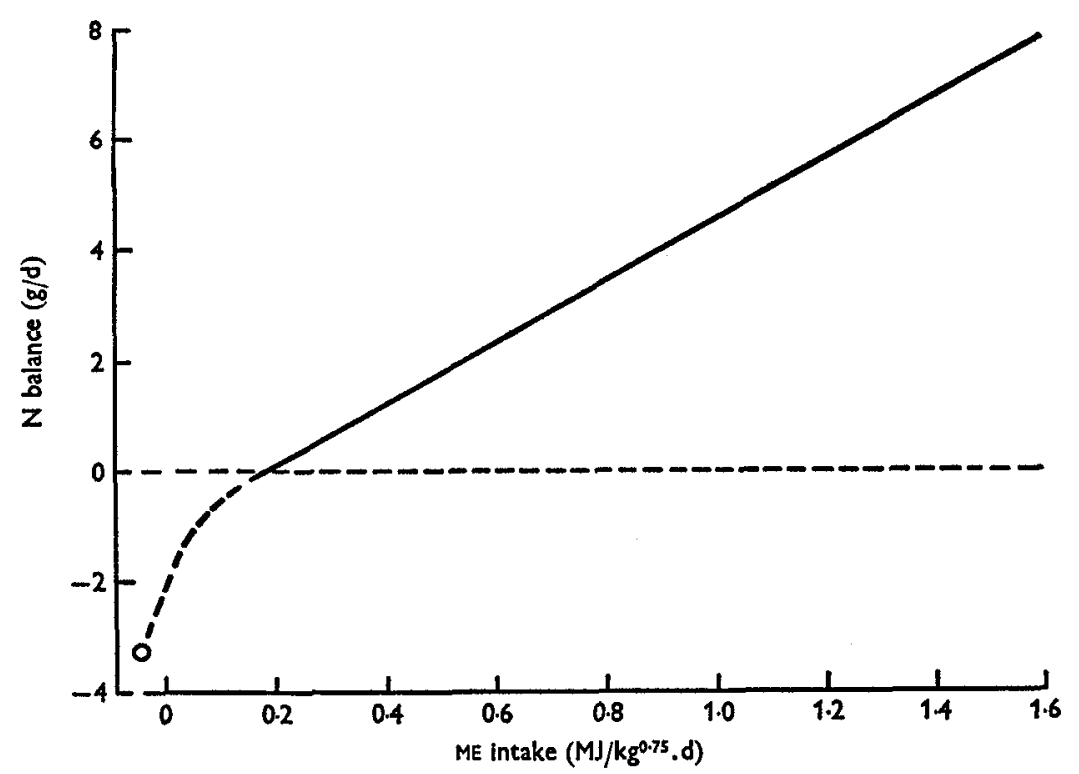

Fig. 5. Relationship between metabolizable energy (ME) intake (MJ/ $\mathrm{kg}^{0.75}$ per d) and nitrogen balance $(\mathrm{g} / \mathrm{d})$ for lambs weighing $5 \mathrm{~kg}$. ___, Predicted from equation 4 (p. 404) over the range of intakes used to establish that equation; $O$, predicted value for fasted lambs (equation 5 , p. 407); - - , the possible relationship for the range of $M B$ intakes for which results were not obtained.

$0.23 \mathrm{~W}_{\mathrm{m}}(\mathrm{MJ} / \mathrm{d})$ irrespective of body-weight. For $\mathrm{ME}$ intakes above $0.23 \mathrm{~W}_{\mathrm{m}}(\mathrm{MJ} / \mathrm{d})$ $\mathrm{N}$ balance/unit $\mathrm{W}_{\mathrm{m}}$ was linearly related to, and decreased with, $\mathrm{W}_{\mathrm{m}}$ and the rate of decrease was greatest at the highest levels of intake. For ME intakes below $0.23 \mathrm{~W}_{\mathrm{m}}(\mathrm{MJ} / \mathrm{d}) \mathrm{N}$ balance/unit $\mathrm{W}_{\mathrm{m}}$ was predicted to increase with increasing $\mathrm{W}_{\mathrm{m}}$, but there was only a small number of values for non-fasted animals given energy intakes below this level.

\section{$N$ balance of fasted animals}

$\mathrm{N}$ balance following a $2-4 \mathrm{~d}$ fast was found to be linearly related to $\mathrm{W}_{\mathrm{m}}$ (Fig. 4 ) and was described by the equation:

$$
\left.\begin{array}{rl}
\mathrm{NB}_{\mathrm{fst}}(\mathrm{g} / \mathrm{d})= & -\mathrm{I} \cdot \mathrm{I} 24-0.668 \mathrm{~W}_{\mathrm{m}} \\
\text { SE } 0 \cdot 36 \mathrm{I} & \text { SE } 0.05^{2}
\end{array} \quad \text { (residual SD I.06, } R_{\mathrm{I}}^{2} 0 \cdot 79\right) .
$$

$\mathrm{N}$ balance observed during fasting was several times less than that predicted by either equation $x$ or 4 . The ME intake of fed lambs varied and was as low as 0.15 $\mathrm{MJ} / \mathrm{unit}_{\mathrm{m}}$ per $\mathrm{d}$ and the accuracy of prediction of $\mathrm{N}$ balance using equation 4 was maintained at this level of intake. The relationship between $\mathrm{ME}$ intake and $\mathrm{NB}_{\text {exc }}$ for ME intakes between $\circ$ (fasting) and $0.15 \mathrm{MJ} / \mathrm{unit}_{\mathrm{m}} \mathrm{W}_{\mathrm{m}}$ per $\mathrm{d}$ is, therefore, a matter of conjecture but over some part of the range it must have a considerably greater slope than that predicted by equation 4 . The region of uncertainty is shown (Fig. 5) for a lamb weighing $5 \mathrm{~kg}$. 


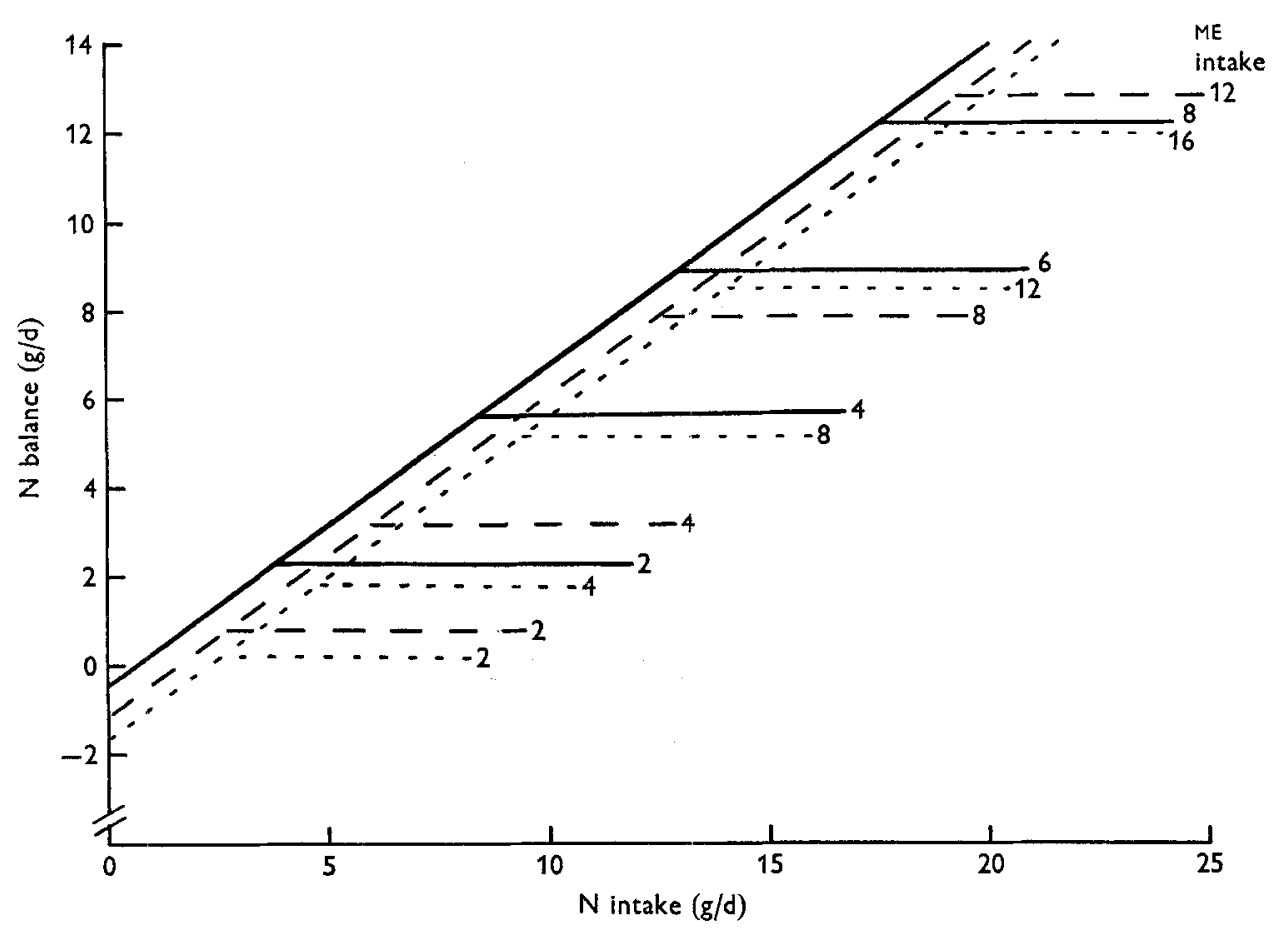

Fig. 6. Fitted relationship between nitrogen balance and $N$ intake for liquid-fed lambs differing in live weight $(-, 5 \mathrm{~kg} ;-----, 15 \mathrm{~kg} ;---, 25 \mathrm{~kg})$ and metabolizable energy (ME) intake $(\mathrm{MJ} / \mathrm{d})$.

\section{Predicted tissue $N$ requirement of growing lambs}

The total $\mathrm{N}$ requirement of the tissues of lambs can be estimated by the factorial method of Blaxter \& Mitchell (1948). This is the sum of the amount of N retained in body tissues and wool when $\mathrm{N}$ absorption is not limiting, and the total endogenous losses of $\mathrm{N}$ in urine and faeces. The effects of ME intake and live weight on the tissue requirement for $\mathrm{N}$ of male cross-bred lambs housed in metabolism cages can therefore be derived from the addition of $0.148 \mathrm{~W}_{\mathrm{m}}$ (equation $\mathrm{I}$ ) to equation 4 giving:

total $\mathrm{N}$ requirement $(\mathrm{g} / \mathrm{d})=2.017 \mathrm{ME}-0.253 \mathrm{~W}_{\mathrm{m}}-0.106 \mathrm{~W}_{\mathrm{m}} \times \mathrm{ME}+0.024 \mathrm{~W}_{\mathrm{m}}{ }^{2}$.

\section{DISCUSSION}

Results presented in this paper provided quantitative information about the influence of live weight and the intake of protein and energy on $\mathrm{N}$ balance in liquid-fed lambs. The predicted relationships between $\mathrm{N}$ balance and $\mathrm{N}$ absorption for lambs of various live weights and ME intakes are given in Fig. 6. In agreement with earlier findings from several species of mammals (see Munro, 1964), the results showed that, when lambs received insufficient protein, $\mathrm{N}$ balance was independent of $\mathrm{ME}$ intake and was linearly related to $\mathrm{N}$ absorption; the slope of the relationship was determined from the $\mathrm{BV}$ of absorbed protein (equation 3). Furthermore, the results 
suggested that under conditions of inadequate protein absorption, $\mathrm{N}$ balance was influenced by live weight. For any given level of $\mathrm{N}$ absorption, $\mathrm{N}$ balance in lightweight lambs was greater than that in heavy-weight lambs. Inowever the relationships between $\mathrm{N}$ balance and $\mathrm{N}$ absorption for lambs of different weights were parallel. The total endogenous loss of $\mathrm{N}$, as indicated by extrapolation to zero $\mathrm{N}$ absorption was proportional to $\mathrm{W}_{\mathrm{m}}$. Brody (1945) also showed that the endogenous $\mathrm{N}$ loss of mature animals of many species, differing widely in body size, is related to $W_{m}$, but this has not previously been found for growing animals of one species.

When $\mathrm{N}$ absorption was in excess of requirement, $\mathrm{N}$ balance was unaffected by $\mathrm{N}$ absorption, within the levels described in this paper, but linearly related to ME intake in fed animals of the same weight. Similar findings have been reported for mature and juvenile rats (Munro \& Naismith, 1953; Miller \& Payne, 1963), as well as for milk-fed calves (Blaxter \& Wood, 1952). These results indicated that for ME intakes above that needed for positive $\mathrm{N}$ balance, a constant proportion of $\mathrm{ME}$ intake is used in protein synthesis for animals of any given weight. 'This concept is contrary to the suggestion of Blaxter ( 1962 ) that the rate of protein deposition decreases progressively as $\mathrm{ME}$ intake was raised above maintenance in animals of a given weight.

For lambs receiving excess dietary $\mathrm{N}$ and a constant $\mathrm{ME}$ intake, $\mathrm{N}$ balance decreased as body-weight of the lambs increased. Therefore, less of the energy available for growth was directed towards protein synthesis, and more was directed towards lipogenesis, as the animals became heavier. Graham \& Searle (1972), from a study of calorimetric results for sheep and cattle, suggested that the fraction of energy storage that appears in protein decreases from $30-35 \%$ at low body-weights to $10-15 \%$ in fully-grown animals. The results of the present study showed, however, that the effect of changes in live weight on $\mathrm{N}$ balance were dependent on ME intake, and the greatest influence was found when $\mathrm{ME}$ intake/unit $\mathrm{W}_{\mathrm{m}}$ was highest (Fig. 3). When lambs were given a ME intake of only c. $0.23 \mathrm{MJ} / \mathrm{unit}_{\mathrm{m}}$ per $\mathrm{d}, \mathrm{N}$ balance/unit $\mathrm{W}_{\mathrm{m}}$ was unaffected by live weight (Fig. 3 b). At this level of intake, there was a small positive $\mathrm{N}$ retention that could all be accounted for in wool growth, and there was probably little change in the protein content of body tissues. A ME intake of $c .0 .23 \mathrm{MJ} / \mathrm{unit} \mathrm{W}_{\mathrm{m}}$ per $\mathrm{d}$ therefore appears to be about the level required by lambs for the maintenance of body protein.

$\mathrm{N}$ loss during fasting was several times greater than that predicted from the extrapolation of equations established for fed lambs. Allison, Anderson \& Sceley (1947) have also demonstrated that $\mathrm{N}$ excretion in dogs increased substantially when ME intake was reduced to one-quartcr of their maintenance requirement. Furthermore, the heat loss of fasted sheep has been shown to be greater than predicted from an extrapolation of the relationship between ME intake and heat production (Graham \& Searle, 1972). Much of the increase in heat production could be explained by an increase in body protein catabolism, because more heat is lost from the oxidation of protein than from the oxidation of body lipids with the same energy content (Chudy \& Schiemann, I969). It therefore appears that below a certain ME intake the rate of mobilization of body protein is increased, but there is insufficient information to define this intake. 


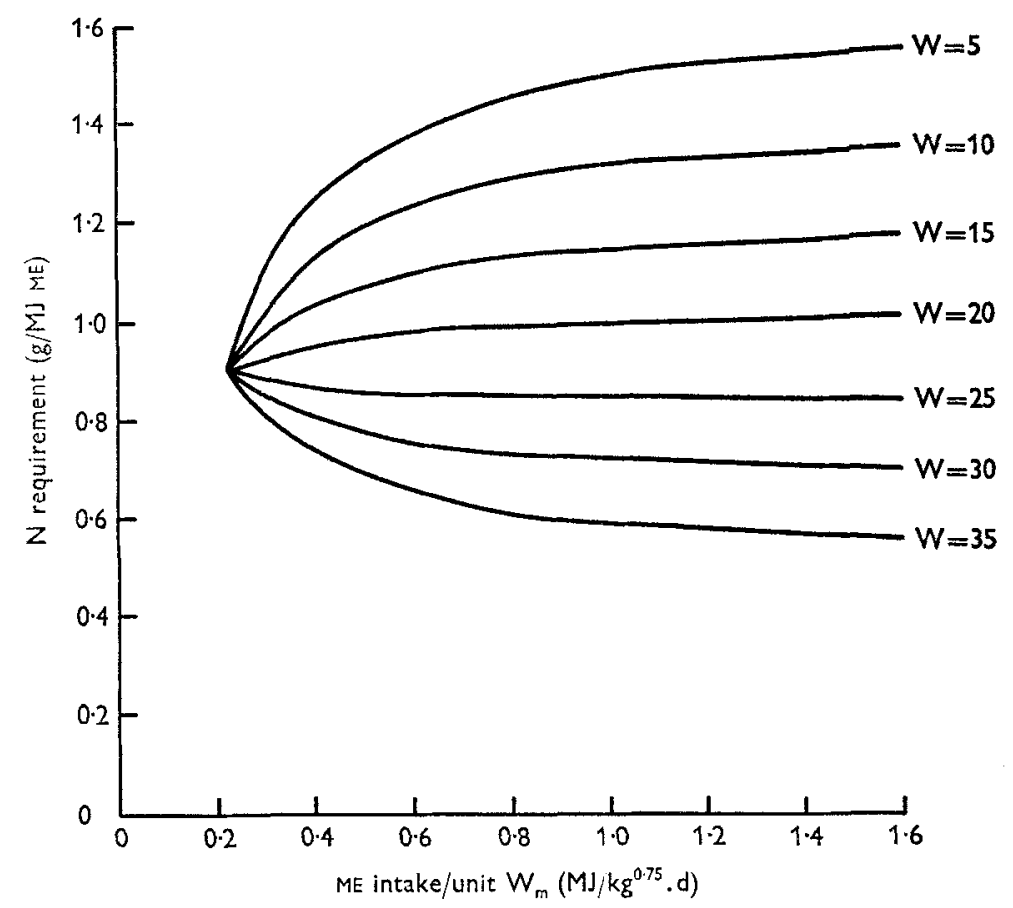

Fig. 7. Predicted relationship between nitrogen requirement/unit metabolizable energy (ME) intake and ME intake/unit metabolic body-weight $\left(W_{m}\right)$ for liquid-fed lambs of between 5 and $35 \mathrm{~kg}$ live-weight (W).

The effects of live weight and ME intake on $\mathrm{N}$ balance described in this paper apply only to one particular breed of male lambs housed in individual metabolism cages with environmental temperatures unlikely to induce cold stress. These interrelationships may differ in detail for lambs of different breeds, for female lambs of the same breed and for lambs subjected to higher levels of exercise or cold-stress conditions, since all these factors could alter the proportion of ME directed towards protein synthesis. Nevertheless, the equations developed in this paper can be used in combination with information about basal metabolic rate and the efficiency of utilization of ME for maintenance and for production, to assess the likely effects of body-weight, plane of nutrition and protein content of the diet on the growth and body composition of lambs (Black, 1974). Miller \& Payne (1963), using results from growing rats, developed equations describing the effects of protein and energy intake on $\mathrm{N}$ balance. They suggested that these equations could be used to assess the $\mathrm{N}$ balance, growth rates, protein requirement and body composition of many mammals including humans and domestic livestock. However, it is unrealistic to use relationships established for juvenile rats to predict the performance of other mammals or even adult rats because of differences both between and within species in the partition of energy between protein synthesis, lipogenesis and maintenance requirements.

The total $\mathrm{N}$ requirement of lambs $(\mathrm{g} / \mathrm{d})$ was evaluated using equation 6 . It follows from this equation that for animals of any particular live weight, $\mathrm{N}$ requirement is a 
linear function of $\mathrm{ME}$ intake. Therefore, equal increments in energy intake give rise to the same increase in $\mathrm{N}$ requirement irrespective of the initial ME intake. For the formulation of diets it is often desirable to express $\mathrm{N}$ requirements in relation to energy intake. The effects of increasing ME intake on this relationship are shown in Fig. 7 where $\mathrm{N}$ requirement/unit ME intake is plotted $v . k$ (ME intake/unit $\mathrm{W}_{\mathrm{m}}$ ) for live weights ranging from 5 to $35 \mathrm{~kg}$. When $k$ was $0.23 \mathrm{MJ} / \mathrm{unit} \mathrm{W}_{\mathrm{m}}$ per d, which was presumed to be approximately the intake required for the maintenance of body protein content in lambs, $\mathrm{N}$ requirement was the same $(c .0 .90 \mathrm{~g} \mathrm{~N} / \mathrm{MIJ} \mathrm{ME})$ for all lambs irrespective of live weight. However, as ME intake was increased above $0.23 \mathrm{MJ} / \mathrm{unit}_{\mathrm{m}}$ per $\mathrm{d}, \mathrm{N}$ requirement/unit ME intake was affected by live weight. For lambs with a live weight of $c .23 \mathrm{~kg}\left(10.5 \mathrm{~kg}^{0.75}\right.$ ), N requirement was constant at $0.90 \mathrm{~g} \mathrm{~N} / \mathrm{MJ}$ ME irrespective of the energy intake. At other live weights the relationship between $\mathrm{N}$ requirement/unit ME intake and $k$ was curvilinear and approached an asymptotic value which was a function of live weight, decreasing from $\mathrm{r} \cdot 67$ to $0.50 \mathrm{~g} \mathrm{~N} / \mathrm{MJ}$ ME as the live weight of lambs increased from 5 to $35 \mathrm{~kg}$. Therefore, for lambs of any live weight less than $23 \mathrm{~kg}$, the $\mathrm{N}$ requirement/unit ME intake increased as the ME intake was increased, but for lambs of a live weight greater than $23 \mathrm{~kg}$ the requirement decreased with increasing $M E$ intake.

It is generally assumed that the protein requirement of animals/unit energy intake increases as intake is increased (Preston, 1966; Agricultural Research Council, I967; Andrews \& Ørskov, 1970), but the results presented here showed that this was true only for light-weight lambs and the opposite situation was found as lambs approach maturity. The decrease in the asymptotic value for $\mathrm{N}$ requirement/unit ME intake as live weight increased was a reflexion of the change in the partition of $\mathrm{ME}$ intake during growth between protein synthesis and lipogenesis as animals become heavier. It can be seen from equation 6 that, for lambs of a constant weight, the asymptotic value also represented the increase in $\mathrm{N}$ requirement associated with a unit increase in ME intake. 'This asymptote may be regarded as the $\mathrm{N}$ requirement for growth. It appeared therefore that, in contrast to lambs weighing less than $23 \mathrm{~kg}$, the $\mathrm{N}$ requirement/unit ME intake for lambs weighing more than $23 \mathrm{~kg}$ was less for growth than it was for the maintenance of body protein content. It was suggested previously (Black et al. 1973) that the $\mathrm{N}$ requirements/unit ME intake are virtually constant for lambs of a single live weight, consuming the range of levels of $\mathrm{ME}$ intakes associated with ad lib. feeding. It can be seen from Fig. 7 that this statement would apply in general, and was most appropriate for those lambs weighing $c .23 \mathrm{~kg}$.

Because of large variations in the efficiency of utilization of $M E$ in lambs, depending on the particular substrates absorbed from the digestive tract, it has been suggested (Black et al. 1973) that the estimates of $\mathrm{N}$ requirement would be more useful for diet formulation if they were expressed in terms of net energy (NE) rather than ME. Since $\mathrm{NE}$ was not measured in these experiments it must be estimated, and the accuracy of this estimation is somewhat dubious because the efficiency of utilization of the diets in lambs at many of the higher live weights has not been measured. However, it was considered that the expression of $\mathrm{N}$ requirements in terms of an estimated $\mathrm{NE}$ intake was essential if the predictions were to be applied to ruminant lambs, as the efficiency 
of utilization of $\mathrm{ME}$ is vastly different in ruminants compared with milk-fed lambs. Until more precise information becomes available, NE intake of the individual lambs was calculated by making the following assumptions: (a) basal metabolic rate (BMR, $\mathrm{kJ} / \mathrm{d}$ ) of milk-fed lambs is given by the equation:

$$
\mathrm{BMR}=(\mathrm{I}+0.23 L)\left(257 \mathrm{~W}_{\mathrm{m}} \epsilon^{-0.08 A}+2 \cdot 8 G+46 D\right),
$$

when $A$ is age (years), $G$ is live-weight gain $(\mathrm{g} / \mathrm{d}), D$ is digestible energy intake (MJ/d) and $L$ is the fraction of digestible energy intake from milk, therefore $L=\mathrm{I}$ for the liquid-fed lambs of this paper (from Graham et al. 1974); (b) the efficiency of utilization of ME for maintenance $\left(k_{\mathrm{m}}\right)=0.84$ (value obtained from the efficiency needed to provide the ME intake for maintenance for a $6 \mathrm{~kg}$ lamb fed on whole-milk powder, determined by Walker \& Norton (197 $b$ ), when BMR was calculated using the equation of Graham et al. (1974)); (c) the efficiency of utilization of ME for production $\left(k_{\mathrm{p}}\right)=0.70$ (Walker \& Norton, 1971 $b$ ).

From these assumptions NE intake for each lamb was calculated as:

$$
\mathrm{BMR}+\left(\mathrm{ME}-\frac{\mathrm{BMR}}{k_{\mathrm{m}}}\right) \times k_{\mathrm{p}}
$$

From the calculated values, the effect of live weight and $\mathrm{NE}$ intake on $\mathrm{N}$ balance when $\mathrm{N}$ intake is in excess of requirement, is then given by the regression equation:

$$
\begin{aligned}
& \mathrm{NB}_{\mathrm{exc}}=2.698 \mathrm{NE}-0.510 \mathrm{~W}_{\mathrm{m}}-0.14^{2} \mathrm{~W}_{\mathrm{m}} \times \mathrm{NE}+0.03 \mathrm{I} \mathrm{W} \mathrm{W}^{2} \\
& \text { SE 0.137 SE 0.109 SE 0.014 SE 0.012 } \\
& \text { (residual SD 0.87, } R_{\mathrm{I}}^{2} 0.93 \text { ). }
\end{aligned}
$$

When the total endogenous losses $(0.148 \mathrm{~W}$ ) are added,

$$
\text { total } \mathrm{N} \text { requirement }(\mathrm{g} / \mathrm{d})=2.698 \mathrm{NE}-0.362 \mathrm{~W}_{\mathrm{m}}-0.142 \mathrm{~W}_{\mathrm{m}} \times \mathrm{NE}+0.03 \mathrm{I} \mathrm{W}_{\mathrm{m}}{ }^{2} \text {. }
$$

Although there are many assumptions involved in its estimation, $\mathrm{NE}$ intake describes the results as well as ME intake does.

'To be consistent with an earlier paper (Black et al. I 973) the protein requirement of lambs can be expressed in terms of $g$ reference-protein/MJ NE, by multiplying the total $\mathrm{N}$ requirement by 6.25 and expressing this per unit NE intake. Application of protein requirements determined from milk-fed lambs to ruminant lambs of the same tissue weight, as well as the formulation of diets for lambs have been discussed previously (Black et al. I973).

The authors thank Dr D. M. Walker and his colleagues of the University of Sydney, Dr R. W. Hodge of the Victoria State Department of Agriculture, Werribee, and Dr N. McC. Graham of the CSIRO, Division of Animal Physiology, Prospect, for allowing them to use their original, and in some instances, unpublished results. Miss $\mathrm{E}$. Smith of CSIRO, Division of Mathematical Statistics, assisted with the statistical analyses. 


\section{REFERENCES}

Agricultural Research Council (1965). The Nutrient Requirements of Livestock No. 2, Ruminants. London: Agricultural Research Council.

Agricultural Research Council (1967). The Nutrient Requirements of Livestock No. 3, Pigs. London: Agricultural Research Council.

Allison, J. B., Anderson, J. A. \& Seeley, R. D. (1947). F. Nutr. 33, 36r.

Andrews, R. P. \& Ørskov, E. R. (1970). F. agric. Sci., Camb. 75, I I.

Balch, C. C. (1967). Wld Rev. Anim. Prod. 14, 84.

Black, J. L. (1974). Proc, Aust. Soc. Anim. Prod. 1o, 2 I 1.

Black, J. L., Pearce, G. R. \& Tribe, D. E. (1973). Br. Y. Nutr. 30, 45.

Blaxter, K. L. (1962). The Energy Metabolism of Ruminants. London: Hutchinson Scientific and Technical.

Blaxter, K. L. \& Mitchell, H. H. (1948). F. Anim. Sci. 7, 351.

Blaxter, K. L. \& Wood, W. A. (1952). Br. $\mathscr{~ F . ~ N u t r . ~ 6 , ~ 1 . ~}$

Brody, S. (1945). Bioenergetics and Growth. New York: Reinhold.

Chudy, A. \& Schiemann, R. (1969). Publs Eur. Ass. Anim. Prod. no. 12, p. I61.

Cornish, E. A. (1950). Aust. F. Sci. Res. B 3, 178.

Graham, N. McC. \& Searle, T. W. (1972). Aust. F. agric. Res. 23, 97.

Graham, N. McC., Searle, T. W. \& Griffiths, D. A. (1974). Aust. F. agric. Res. 25, 957.

Hegsted, D. M. \& Neff, R. (1970). F. Nutr. Ioo, I I73.

Hodge, R. W. (r97r). Nutritional studies with the young ruminant. PhD Thesis, University of Melbourne.

Kleiber, M. (1 969). Publs Eur. Ass. Anim. Prod. no. 12, p. 505.

Markowitz, J., Archibald, J. \& Downie, H. G. (I964). Experimental Surgery 5th ed. Baltimore: Williams and Wilkins.

Miller, D. S. \& Payne, P. R. (1963). F. theoret. Biol. 5, 398.

Munro, H. N. (1964). In Mammalian Protein Metabolism Vol. I, p. 38ז [H. N. Munro and J. B. Allison, editors]. London and New York: Academic Press.

Munro, H. N. \& Naismith, D. J. (r953). Biochem. 7. 54, rgr.

Norton, B. W. (1968). The nutrition of the milk-fed lamb: $N$ retention during growth. PhD Thesis, University of Sydney.

Norton, B. W. \& Walker, D. M. (1971 a). Br. F. Nutr. 26, I.

Norton, B. W. \& Walker, D. M. (197 $b$ ). Br. F. Nutr. 26, 7 .

Ørskov, E. R. (I970). In Nutrition Conference for Feed Manufacturers p. 20 [H. Swan and D. Lewis, editors]. London: J. \& A. Churchill.

Preston, R. L. (1966). F. Nutr. 90, 157.

Walker, D. M. (1967). Br. F. Nutr. 21, 289 .

Walker, D. M. \& Cook, L. J. (I967). Br. F. Nutr. 21, 237.

Walker, D. M., Cook, L. J. \& Jagusch, K. T. (I967). Br. F. Nutr. 21, 275.

Walker, D. M. \& Norton, B. W. (I 971 $a$ ). Br. $\mathscr{F}$. Nutr. 26, 15.

Walker, D. M. \& Norton, B. W. (I97 I b). F. agric. Sci., Camb. 77, 363 . 